democratize public spaces through certain legal and institutional changes, including institutionalizing gender into public institutions (p. 322).

The book's major strength is its balance between contemporary and historical analysis. Published in the middle of this decade, the book offers a well-timed yet interminable interrogation of transfeminist theory and practice. The book's timeliness lies in its origins. Its conception during a workshop of feminist journal editors coincided with the extinguishing of lives in the Twin Towers of the World Trade Centre in New York on 11 September 2001. Birthed in the aftermath of death and destruction, the questions posed in this volume published four years later still seem relevant. In fact the book escapes obsoleteness and embarks on a vital journey of self-reflection by learning from geographic or historical differences within the transfeminist movement to examine ways in which women struggle against structural, economic, political, institutional and practical challenges in their socio-historical context. By embarking on this journey of reflection, the book wades uncertainly toward answering queries Angela Miles situates in the socio-political context of globalization and its subsequent militarization, but it does ultimately address them. However, the book's chronicles of struggles, summed up in Alda Facio's lyrical conclusion, uphold feminist values such as solidarity and peace as strategies against globalization. Overall, the editors' careful selection of essays from authors with vast and varied experiences creates a juxtaposition which allows the book to escape the traps of reactive engagement with the pervasive discourse of 'anti-terrorism', thus providing an enjoyable read that will interest academics, activists, and advocates alike.

doi: $10.1057 /$ palgrave.fr. 9400402

Chinwe Madubuike

\title{
Women making news: gender and the women's periodical press in Britain
}

Michelle Elizabeth Tusan; University of Illinois Press, Champaign, IL, USA, 2005, 320p, ISBN 0-252-03015-X, \$45 (Hbk, in USD)

The story of the women's advocacy press in Britain may be one of 'a series of failed experiments' ( $p .243$ ). Yet Michelle Tusan's analysis of these repeated efforts is not in vain, as it adds depth to our understandings of the connections between activist women from the mid-nineteenth to the mid-twentieth century. It documents the persistent attempts made by women to create an imagined community of their own through the printed word. It also traces the real-world development of the women's press as an industry and alternative infrastructure, which took advantage of new technologies and modes of economic organization 
such as vertical integration. The focus on the industry and its product as discursive institutions also contributes to women's history by showing, for example, that there was a growth in the number of newspapers and periodicals for women during the First World War, not the patriotic diminution posited by much historical literature.

The first five chapters centre on the women's advocacy press before the end of the First World War, leaving just one chapter on the interwar period. Each chapter of the book is grounded in its historical context, in terms of the journalism market as well as gender and laws in society. The bulk of the book traces the origins of the women's political press as a business, the mutual aid networks that women built, their public interventions in the representation of women - notably around the 'New Woman' debate, their contribution to the Edwardian liberal imperial concept of Britishness and their negotiations between critiquing and supporting the state during wartime. A number of common threads emerge in terms of both issues and organization.

Tusan provides evidence of the development of a discourse of political womanhood, such as a set of concerns, for example, employment, education, suffrage and the welfare of women and children, that the advocacy press legitimated as 'women's issues'. Within this discourse, certain behaviours which were proscribed by mainstream gender ideology, such as selling women's newspapers in the street, were important to the individual becoming a female activist, and as such were mythologized by the very papers she read and sold. The central characterization of this woman activist was distinctly white publications which looked beyond British borders did so in a similarly imperial spirit as their male counterparts and were much concerned with 'civilizing' missions. However, a small number of titles for the British working class woman persisted in attempting to represent their own point of view, even if their leaderships still tended to come from higher classes - Sylvia Pankhurst's Dreadnought being a case in point.

The industry experimented with hybrid forms of economic maintenance, as another common thread was a collective inability to make profit. Tusan highlights 'the importance of patronage' (p. 54), how usually rich and often aristocratic women have mainly been the owners, editors and organizers, willing to continue to fund failing papers. Yet economic necessity and the small numbers of leadership figures enabled a more cooperative business model across the industry, rather than the fierce competition that characterized the mainstream market.

The achievement of the (limited) franchise in 1918 and the mainstream press's increasing focus on the female reader as the household consumer meant the decline of the women's advocacy press. The weekly review Time and Tide (19201963) is discussed as the 'final chapter' ( $p .221$ ), a story of splits between the 'old' equality struggle and the 'new' or 'welfare' feminism, which was at least in 
part catered for by the daily news. It is this chapter particularly which reveals a limitation on one half of Tusan's stated aims - that of uncovering the 'making of a particular kind of female subject' (p. 1), as it fails to follow her turn towards the mainstream papers to discover what attracted her to them.

Women who were deeply involved in the women's press reveal in their correspondence, autobiographies and addresses to readers ways in which their gendered identities are forged in contact with advocacy journalism. Each female activist entered into complex negotiations with traditional, male expectations of their social role in order to break the rules by entering into the male sphere of public life but to minimize the consequent disapprobation. Powerful and colourful examples are provided from the writings of public women. However, the book does not deal with media theories that warn against the possibility of 'reading off' an audience subject position from the text. Undoubtedly those activist women believed strongly in the work they performed and its 'transformative potential' ( $p$. 241). They addressed readers in ways clearly intended to invite their participation not only in the imagined community, but in real action. Yet there is little evidence for the ways in which these messages were received, except from those who became producers. There is no discussion of variety within subject positions, although it may be supposed a female journalist and a woman who merely read the occasional issue might have felt differently about their female activist identities. However, few authors have achieved the negotiations between Western historical and media studies methodologies necessary for such an undertaking, which requires a widespread initiative across countries, institutions and faculties.

Sadie Clifford

doi:10.1057/palgrave.fr. 9400391

\section{Women and journalism}

Deborah Chambers, Linda Steiner and Carole Fleming; Routledge, London and New York, 2004, 296p, ISBN 0-415-27445-1, £17.99 (Pbk); ISBN-13 978-0415274456, £60 (Hbk)

The main focus of this book is the production of journalism and women's role within it. Written by senior feminist academics, it is a comprehensive overview of the key developments in the profession since 1850, in both Britain and the United States. Within its themed chapters, it alternates discussion of the British and American experience, so it has an interrupted narrative. Rather than reading it from start to finish, therefore, it is probably most useful as a resource, to be read in sections for a specific purpose. It is thus very helpful for students in a number of disciplines - mainly communication or media studies but also for women's studies and research into media institutions and working practices. 